\title{
Liquid Perfluorochemical Inhibits Inducible Nitric Oxide Synthase Expression and Nitric Oxide Formation in Lipopolysaccharide-Treated RAW 264.7 Macrophages
}

\author{
Li-Ping Chang ${ }^{1}$, Yuan-Shu Lai ${ }^{2}$, Chang-Jer $\mathrm{Wu}^{3}$, and Tz-Chong Chou ${ }^{4, *}$ \\ ${ }^{I}$ Department of Radiation Oncology, Tri-Service General Hospital, Taipei 114, Taiwan \\ ${ }^{2}$ Taipei City Hospital, Taipei 10341, Taiwan \\ ${ }^{3}$ Department of Food Science, National Taiwan Ocean University, Keelung 20224, Taiwan \\ ${ }^{4}$ Department of Physiology, National Defense Medical Center, Taipei 114, Taiwan
}

Received February 8, 2009; Accepted July 29, 2009

\begin{abstract}
Partial liquid ventilation with various types of perfluorocarbon (PFC) has been shown to be beneficial in treating acute lung injury, a clinical outcome that may involve the anti-inflammatory activity of PFC. FC-77 is a type of PFC with relatively higher vapor pressure and evaporative loss than other PFCs during partial liquid ventilation. Overproduction of nitric oxide (NO) by inducible nitric oxide synthase (iNOS) has been proposed to play a crucial role in the pathogenesis of inflammatory diseases. However, whether the iNOS/NO pathway is affected by FC-77 is unknown. Thus, the aim of this study was to investigate whether FC-77 inhibits iNOS expression and NO production in lipopolysaccharide (LPS)-treated RAW 264.7 macrophages. We found that treatment with FC-77 significantly attenuated LPS-induced iNOS expression/activity and production of $\mathrm{NO}$ and reactive oxygen species (ROS). FC-77 also attenuated LPS-induced pro-inflammatory cytokine formation, but enhanced interleukin-10 production. Furthermore, the LPS-induced degradation of cytosolic $\mathrm{I} \kappa \mathrm{B}-\alpha$ and activation of nuclear transcription factor- $\kappa \mathrm{B}(\mathrm{NF}-\kappa \mathrm{B})$ were also inhibited by FC-77. In conclusion, the present study is the first to demonstrate that FC-77 decreases LPS-induced NO production in macrophages, which may be associated with the suppression of pro-inflammatory cytokines, and ROS production, as well as NF- $\kappa \mathrm{B}$ activation. These results also provide a novel explanation for its anti-inflammatory activity.
\end{abstract}

Keywords: perfluorocarbon, nitric oxide, lipopolysaccharide, cytokine, macrophage

\section{Introduction}

The liquid perfluorocarbon (PFC), which possesses unique physical characteristics including high solubility for oxygen and $\mathrm{CO}_{2}$ as well as low surface tension, has been widely used in partial liquid ventilation. Several studies have demonstrated improvement in gas exchange and pulmonary function after partial liquid ventilation with PFC, such as perflubron, in the lung injury model $(1-3)$. Fluorinert (FC-77), a type of PFC, has a relatively higher vapor pressure and evaporative loss

*Corresponding author. tcchou@ms5.hinet.net

Published online in J-STAGE

doi: 10.1254 /jphs.09043FP and a lower viscosity and radiodensity than other PFCs during partial liquid ventilation (4). Theoretically, FC-77 may evaporate from the lungs faster than other PFCs after liquid ventilation, which may hasten recovery from liquid-assisted ventilation (5). Furthermore, administration of FC-77 improved pulmonary compliance and histopathology compared with conventional mechanical ventilation in a piglet model of acute lung injury (4). It is well known that inflammation plays a crucial role in the pathogenesis of acute lung injury (6), and antiinflammatory therapy may be a beneficial strategy in treating severe lung injury. In addition to the improvements in pulmonary physiology, an anti-inflammatory activity of perflubron due to inhibition of the production of reactive oxygen species (ROS) and pro-inflammatory 
cytokines $(7-10)$ was reported, which may account for its beneficial effect in acute lung injury. Importantly, our previous study demonstrated that FC-77 reduced prostaglandin $\mathrm{E}_{2}$ formation and cycloxygenase- 2 induction in endotoxin-treated macrophages (11). Accordingly, we propose that FC-77 may exhibit an antiinflammatory activity. However, the anti-inflammatory mechanisms of FC-77 remain unclear.

Nitric oxide (NO), synthesized by the enzyme nitric oxide synthase (NOS), is an important regulatory/modulatory mediator for several physiological functions (12). However, high output NO production by inducible NOS (iNOS) stimulated by pro-inflammatory cytokines, free radicals, and lipopolysaccharide (LPS) participates in the pathogenesis of inflammatory diseases including sepsis $(13,14)$. The LPS-induced inflammatory response and high mortality were all significantly attenuated in both iNOS-deficient mice or mice treated with iNOS inhibitor $(15,16)$, further suggesting that suppression of iNOS-derived NO overproduction may be a potential strategy for treating inflammatory diseases. Additionally, a large number of activated macrophages often found in injured tissues are major producers of inflammatory mediators including pro-inflammatory cytokines, NO, and ROS, which have been implicated in the pathogenesis of inflammatory diseases $(17,18)$. However, whether FC-77 affects the iNOS/NO pathway in activated macrophages is still unknown. Therefore, in the present study, we tested the effect of FC-77 on LPS-induced iNOS expression, NO production, and nuclear transcription factor- $\kappa \mathrm{B}(\mathrm{NF}-\kappa \mathrm{B})$ activation in macrophages.

\section{Materials and Methods}

\section{Materials}

FC-77 (chemical formula: C8F18, with a purity of $100 \%$ ) was purchased from 3M (St. Paul, MN, USA). To prepare the solution of FC-77 (10\% and 30\%, v/v), pure FC-77 was mixed with Dulbecco's modified Eagle's medium (DMEM) (v/v = 1:9 or 3:7). Antibodies against iNOS (Transduction Laboratories, Lexington, KY, USA), $\alpha$-tubulin (Santa Cruz Biotechnology, Santa Cruz, CA, USA), and $\mathrm{I} \kappa \mathrm{B}-\alpha$ (Cell Signaling Technology, Beverly, MA, USA) were used in this study. Enzymelinked immunosorbent assay (ELISA) kits for tumor necrosis factor- $\alpha$ (TNF- $\alpha$ ), interleukin-6 (IL-6), interleukin-1 $\beta$ (IL-1 $\beta$ ), and interleukin-10 (IL-10) were purchased from Biosource International (Camarillo, CA, USA). Escherichia coli-derived LPS (E. coli serotype 055:B5) was purchased from Sigma Chemical Co. (St. Louis, MO, USA).

\section{Cell culture}

Macrophages (ATCC TIB-71, $1 \times 10^{6}$ cells) cultured in 24-well plates were incubated with FC-77 solution $(10 \%$ or $30 \%, \mathrm{v} / \mathrm{v}) 600 \mu \mathrm{l}$ per well for $24 \mathrm{~h}$ in the presence or absence of LPS $(1 \mu \mathrm{g} / \mathrm{ml})$. As FC-77 is not miscible with the medium, the cell culture plates were agitated using a mechanical shaker at a gentle 60 revolutions/min to ensure contact of the cell layer with FC-77 (7). Because the density of FC-77 is higher than that of the medium, the free FC-77 was on the top layer and could be easily separated from the medium by centrifugation. This top layer was carefully collected with a pipette for nitrite and cytokine determination. The cells were washed twice with PBS buffer to remove residual FC-77 and used to assay activity and expression of iNOS. The cells cultured with DMEM alone acted as the control group.

\section{Experimental design for assays of FC-77 effects}

To measure these mediators properly, cells were incubated with FC-77 for variable times for different assays. To measure levels of nitrite, cytokine, and iNOS expression, the incubation time was $24 \mathrm{~h}$. To measure NOS activity, the cells were incubated with LPS for $24 \mathrm{~h}$; the cells were collected and lysed; the FC-77 was added into the cell lysates for an additional $3 \mathrm{~h}$; and then the NOS activity was measured as previously described (19). For the iNOS mRNA assay, because our preliminary test showed that expression of iNOS mRNA reached a peak after treatment with LPS for $6 \mathrm{~h}$, we used $6 \mathrm{~h}$ for the incubation time of LPS and FC-77. For the assay of $\mathrm{I} \kappa \mathrm{B}-\alpha$ degradation and $\mathrm{NF}-\kappa \mathrm{B}$ activation, the suitable incubation time of LPS and FC-77 was $1 \mathrm{~h}$, as established in the previous study (20). Finally, for ROS determination, the cells were preincubated with FC-77 for $1 \mathrm{~h}$ and then LPS was added for an additional $3 \mathrm{~h}$ to measure ROS production.

\section{Measurement of nitrite and cytokine production}

The concentrations of nitrite, a stable metabolite of $\mathrm{NO}$, and cytokine in the culture medium were determined by using Griess agent and commercial ELISA kits, respectively.

\section{Measurement of NOS activity}

NOS activity was assessed on the basis of $\mathrm{NO}_{2}^{-}$production (19). Briefly, after treatment of FC-77 with cells for $24 \mathrm{~h}$ to activate the NOS activity, the cells were collected and suspended in $40 \mathrm{mM}$ Tris- $\mathrm{HCl}, \mathrm{pH} 8.0$, $1 \mathrm{mM}$ DTT, $100 \mu \mathrm{M}$ PMSF, $10 \mu \mathrm{g} / \mathrm{ml}$ trypsin inhibitor, $5 \mu \mathrm{g} / \mathrm{ml}$ aprotinin, and $10 \mu \mathrm{g} / \mathrm{ml}$ leupeptin at a cell density of $10^{7}$ cells $/ \mathrm{ml}$. Then the cells were disrupted by sonication and centrifuged at $100,000 \times g$ for $30 \mathrm{~min}$ at 
$4^{\circ} \mathrm{C}$. The supernatant (50 $\mu \mathrm{g}$ protein) was incubated with or without $\mathrm{FC}-77$ for an additional $3 \mathrm{~h}$ at $37^{\circ} \mathrm{C}$ in a reaction mixture containing $50 \mathrm{mM}$ Tris- $\mathrm{HCl}, \mathrm{pH} 7.6$, $2 \mathrm{mM}$ L-arginine, $20 \mu \mathrm{M}$ FAD, $20 \mu \mathrm{M}$ tetrahydrobiopterin, $1 \mathrm{mM}$ DTT, and $2 \mathrm{mM}$ NADPH. Then the reaction was stopped by boiling for $3 \mathrm{~min}$ and the level of nitrite was measured by Griess reagent. The level of nitrite in the reaction solution without NADPH and Larginine was subtracted from the experimental values. The NOS activity was expressed as nmol of nitrite/mg protein.

Reverse transcriptase-polymerase chain reaction (RT$P C R$ ) analysis of $i N O S$

Total cellular RNA was isolated from RAW 264.7 macrophages with a QIAGEN RNeasy kit (Hilden, Germany). The cDNA of iNOS and GAPDH were made and amplified by the following published primers of iNOS and GAPDH: iNOS 5'-CTGCAGCACTTGGAT CAGGAACCTG-3' (forward) and 5'-GGGAGTAGC CTGTGTGCACCTGGAA-3' (reverse), GAPDH 5'TGCTGAGTATGTCGTGGAGTCT-3' (forward) and 5'-AATGGGAGTTGCTGTTGAAGTC-3' (reverse). The products were separated on a $2 \%$ agarose gel in TBE buffer and stained with ethidium bromide solution. The density of the bands was detected and quantized by using Photo CaptMw software (Viller Lourmat, Marne-laVallée, France).

\section{Western blotting assay}

Total cellular protein was extracted using lysis buffer [50 mM Tris- $\mathrm{HCl}, \mathrm{pH} 7.4,0.5 \mathrm{M} \mathrm{NaCl}, 1 \mathrm{mM}$ EDTA, $0.05 \%$ SDS, $0.5 \%$ Triton $\mathrm{X}-100$, and $1 \mathrm{mM}$ phenylmethylsulphonyl fluoride (PMSF)]. Then, the cell lysates were centrifuged at $15,000 \times g$ for $10 \mathrm{~min}$ at $4^{\circ} \mathrm{C}$ to collect the supernatant. The protein $(12 \mu \mathrm{g})$ was separated on $7.5 \%$ sodium dodecylsulphate (SDS)-polyacrylamide minigels and then transferred to polyvinylidene difluoride (PVD) membranes (Millipore, Bedford, MA, USA). Nonspecific IgGs were blocked with $5 \%(\mathrm{w} / \mathrm{v})$ skim milk in Tris-buffered saline (TBS: $50 \mathrm{mM}$ Tris$\mathrm{HCl}, \mathrm{pH} 7.5,150 \mathrm{mM} \mathrm{NaCl}, 2.5 \mathrm{mM} \mathrm{KCl}$ ) and incubated for $1 \mathrm{~h}$ at room temperature. Then the membranes were incubated with specific antibodies against iNOS (1:1,000 dilution, Transduction Laboratories) or $\alpha$ tubulin (1:5,000 dilution, Santa Cruz). The bands were visualized by exposure of the membrane to a horseradish peroxidase-conjugated secondary antibody (1:5,000 dilution, Transduction Laboratories) followed by addition of ECL reagent (Amersham International Plc., Buckinghamshire, UK). The relative optical density of bands was quantified by densitometry and normalized with respect to $\alpha$-tubulin.
Electrophoretic mobility shift assay (EMSA)

The nuclear extracts were prepared by using NE-PER nuclear and cytoplasmic extraction reagents (Pierce, Rockford, IL, USA). The non-radioactive EMSA was performed by using a nuclear transcription factor- $\kappa \mathrm{B}$ (NF- $\kappa \mathrm{B})$ EMSA kit according to the manufacturer's instructions (Panomics, Inc., Redwood City, CA, USA). Briefly, nuclear protein $(20 \mu \mathrm{g})$ was added into the biotinylated oligonucleotides containing the NF- $\kappa$ Bbinding site for $30 \mathrm{~min}$ at room temperature, and then the mixture was separated in a nondenaturing polyacrylamide gel ( $6 \%$ with $2.5 \%$ glycerol) and finally transferred on a Biodyne B $(0.45 \mu \mathrm{m})$ positively charged nylon membrane (Pall Schweiz AG, Basel, Switzerland). The blots were detected with ECL reagent (Amersham International Plc.).

\section{Measurement of intracellular ROS formation}

RAW 264.7 macrophages $\left(10^{7}\right.$ cells $\left./ \mathrm{ml}\right)$ were preincubated with FC-77 for $1 \mathrm{~h}$ and LPS was added for another $1 \mathrm{~h}$. Then, $10 \mu \mathrm{M} \mathrm{2',7'-dichlorofluorescin}$ diacetate (DCF-DA, Sigma Chemical Co.) was added and incubated for $30 \mathrm{~min}$ at $37^{\circ} \mathrm{C}$ in the dark. Following oxidation by peroxides, the fluorescence of $2^{\prime}, 7^{\prime}$ dichlorofluorescin was measured at $485 \mathrm{~nm}$ excitation and $530 \mathrm{~nm}$ emission by a cytofluorometer (Chronolog, Malvern, PA, USA).

\section{Cell viability assay}

Cell viability was assessed by the mitochondriadependent reduction of 3-(4,5-dimethylthiazol-2-yl)diphenyltetrazolium bromide (MTT) to formazan as previously described (15).

\section{Statistical analyses}

Data are expressed as means \pm S.E.M. All results were analyzed by one-way ANOVA followed by a multiple comparison test (Scheffe test). A $P$ value less than 0.05 was considered statistically significant.

\section{Results}

\section{Effect of FC-77 on nitrite formation and NOS activity}

Treatment with FC-77 (10\% or $30 \%, v / v)$ for $24 \mathrm{~h}$ dose-dependently inhibited LPS-induced accumulation of nitrite production and iNOS activity compared to those of LPS (alone)-treated macrophages (Fig. 1).

\section{Effect of FC-77 on iNOS induction}

Addition of FC-77 also inhibited the LPS-induced iNOS protein and mRNA expression in macrophages compared to those of LPS (alone)-treated alone macrophages (Fig. 2). 
A

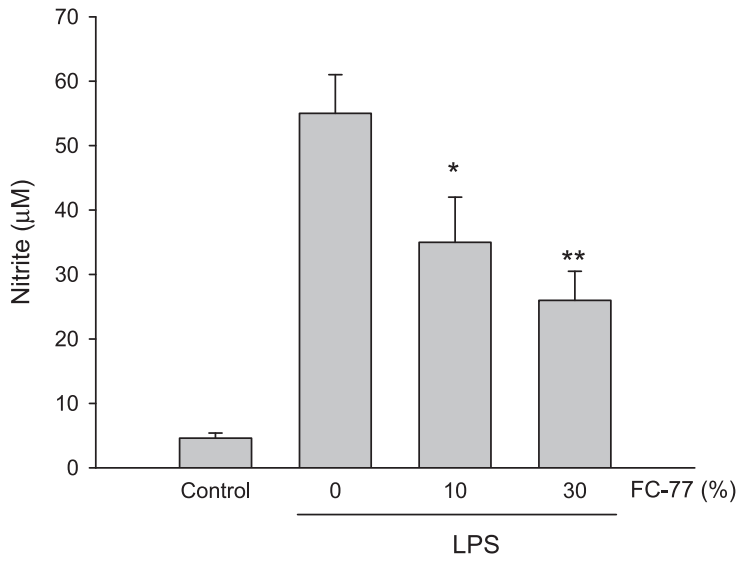

B

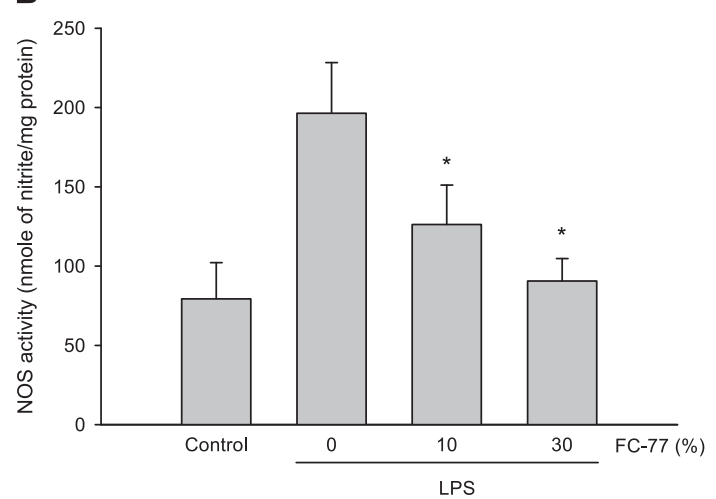

Fig. 1. Effect of FC-77 on nitrite production and NOS activity in LPS-treated RAW 264.7 macrophages. A) After treatment of cells with LPS $(1 \mu \mathrm{g} / \mathrm{mL})$ for $24 \mathrm{~h}$, the level of nitrite in the medium was measured. B) After treatment of cells with LPS for $24 \mathrm{~h}$, cell lysates were prepared and incubated with or without FC-77 for an additional $3 \mathrm{~h}$. The NOS activity was measured as described in the Methods section. The cells cultured with DMEM alone served as a control group. Values of each group are expressed as the mean \pm S.E.M. ( $\mathrm{n}=6$, each group). $* P<0.05, * * P<0.01$, compared with that in LPS (alone)-treated cells.

\section{Effect of FC-77 on cytokine formation}

Treatment with FC-77 significantly decreased the LPS-induced TNF- $\alpha$, IL- $1 \beta$, and IL- 6 formation, but enhanced IL-10 production (Fig. 3).

\section{Effect of $\mathrm{FC}-77$ on $\mathrm{NF}-\kappa \mathrm{B}$ activation}

Since NF- $\kappa$ B is a key regulator for the induction of iNOS and cytokines, the effect of FC-77 on NF- $\kappa$ B activation was also evaluated. Our results showed that FC-77 attenuated LPS-induced degradation of cytosolic $\mathrm{I} \kappa \mathrm{B}-\alpha$ and activation of $\mathrm{NF}-\kappa \mathrm{B}$, as determined by EMSA (Fig. 4).

\section{Effect of FC-77 on ROS production}

To assess whether FC-77 also exerts an antioxidant
A
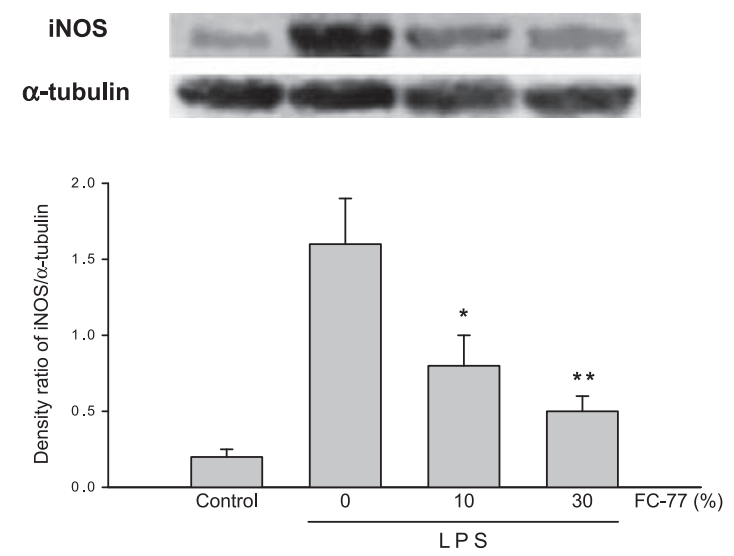

B
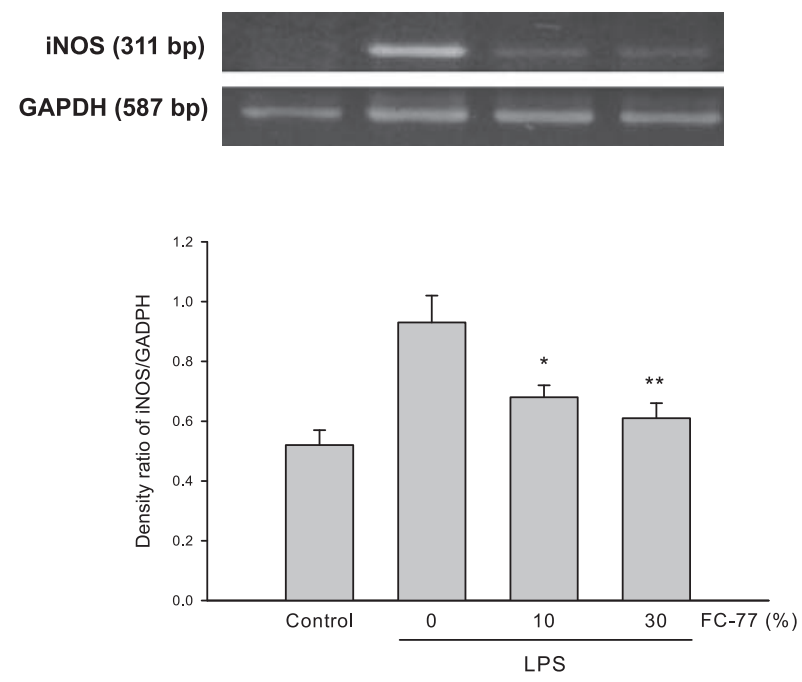

Fig. 2. Effect of FC-77 on iNOS induction in LPS-treated RAW 264.7 macrophages. A) After incubation of cells with LPS for $24 \mathrm{~h}$ in the presence or absence of FC-77, the protein levels of iNOS and $\alpha$ tubulin were determined by western blot analysis. Then, the density ratio of iNOS to $\alpha$-tubulin was calculated. B) Cells were incubated with LPS for $6 \mathrm{~h}$ in the presence or absence of FC-77. The levels of mRNA of iNOS and GAPDH were determined by RT-PCR analysis. Then, the density ratio of iNOS to GAPDH was calculated. Values of each group are expressed as the mean \pm S.E.M of five independent experiments. The cells cultured with DMEM alone served as a control group. ${ }^{*} P<0.05, * * P<0.01$, compared with that in LPS (alone)-stimulated cells.

activity, the intensity of fluorescence of DCF-DAlabeled cells was measured. Addition of LPS to the cells increased the fluorescence by approximately 2 -fold relative to the control. Treatment with FC-77 $(10 \%$ or $30 \%, \mathrm{v} / \mathrm{v})$ significantly decreased LPS-induced fluorescence by $25 \%(P<0.05)$ and $40 \% \quad(P<0.01)$, respectively, compared to LPS (alone)-treated alone macrophages (Fig. 5). 

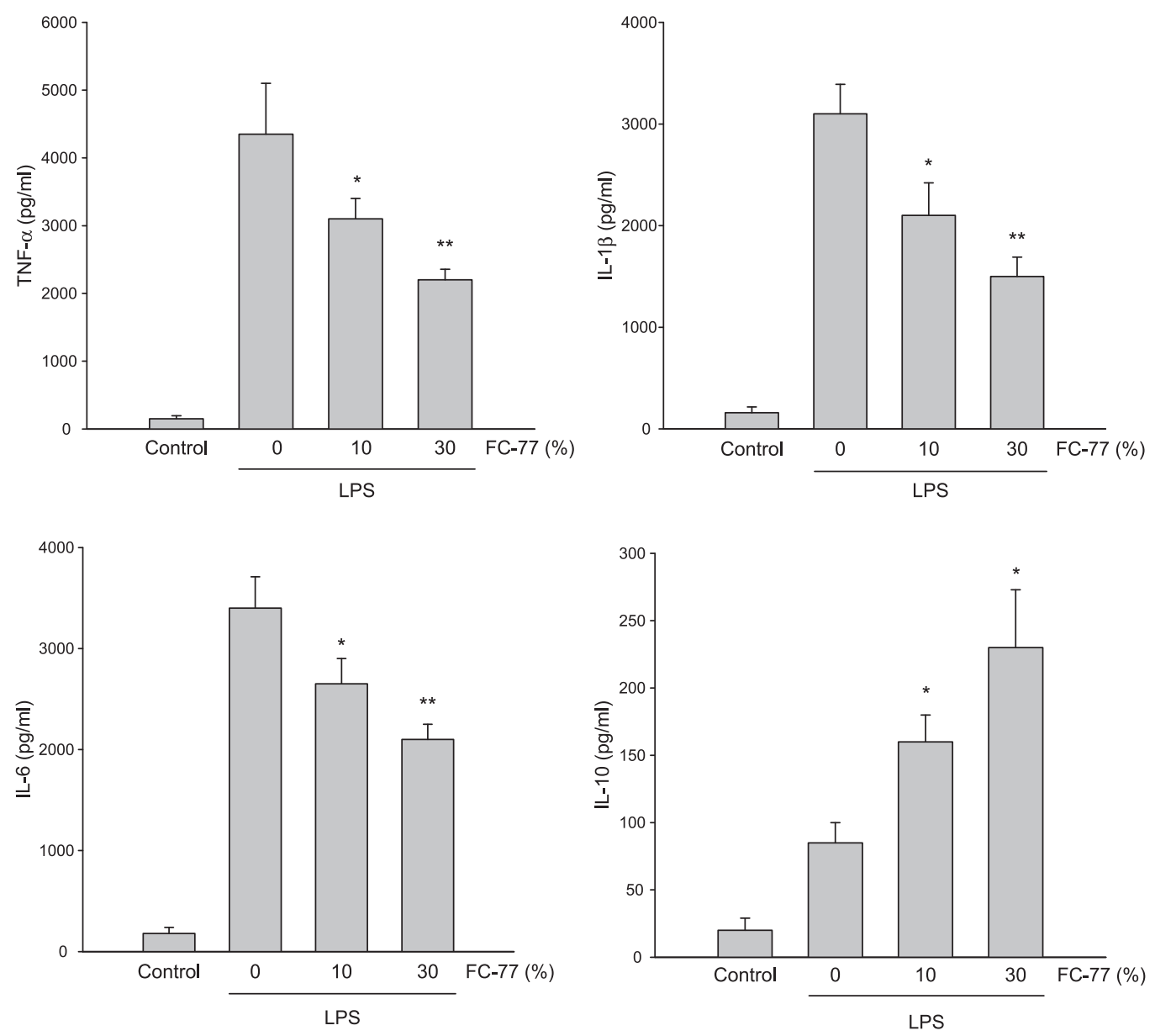

Fig. 3. Effect of FC-77 on the production of cytokines in LPS-treated RAW 264.7 macrophages. After incubation of cells with LPS for $24 \mathrm{~h}$ in the presence or absence of FC-77, the concentrations of TNF- $\alpha$, IL-1 $\beta$, IL- 6 , and IL-10 in the medium were measured. Values of each group are expressed as the mean \pm S.E.M. $\left(\mathrm{n}=6\right.$, each group). ${ }^{*} P<0.05,{ }^{*} P<0.01$, compared with that in LPS (alone)-treated cells.

\section{Effect of FC-77 on cell viability}

The absorbances of MTT in FC-77 alone $(10 \%$ or $30 \%, \mathrm{v} / \mathrm{v}$ )-treated cells were $1.42 \pm 0.13$ and $1.35 \pm$ 0.09 , respectively, compared to that of control cells $(1.56 \pm 0.21)$. There was no statistical difference among these groups, indicating that the cell viability was not affected by the concentration range of FC-77 used in this study. In addition, the nitrite, cytokines, and ROS were not detectable in the FC-77 layer, and FC-77 itself did not alter the basal level of these mediators (data not shown).

\section{Discussion}

In response to LPS, overproduction of NO by iNOS has been implicated as an important mediator in the pathogenesis of inflammation. However, whether the inhibition of NO production is involved in the antiinflammatory activity of FC-77 is unknown. The present study is the first to demonstrate that FC-77 significantly inhibited LPS-induced iNOS induction and NO production in macrophages, which may be associated with attenuation of NF- $\kappa$ B activation and pro-inflammatory cytokine and ROS production.

It is well known that LPS can induce the production of pro-inflammatory cytokines, including TNF- $\alpha$, IL-6, and IL-1 $\beta$, which in turn stimulates iNOS induction (21). Thus, inhibition of pro-inflammatory cytokine formation may be a potential strategy to suppress the iNOS/NO pathway. The current study showed that treatment with FC-77 dose-dependently inhibited LPS-induced TNF- $\alpha$, IL-6, and IL- $1 \beta$ formation, which is similar to the results of perflubron $(7,8)$. On the other hand, IL-10, an antiinflammatory cytokine, has an ability to attenuate LPSinduced NO production by inhibiting pro-inflammatory cytokine and ROS formation $(22,23)$, limiting the availability of iNOS substrate (24), and reducing iNOS expression (25). Compared to perflubron (8), a novel 

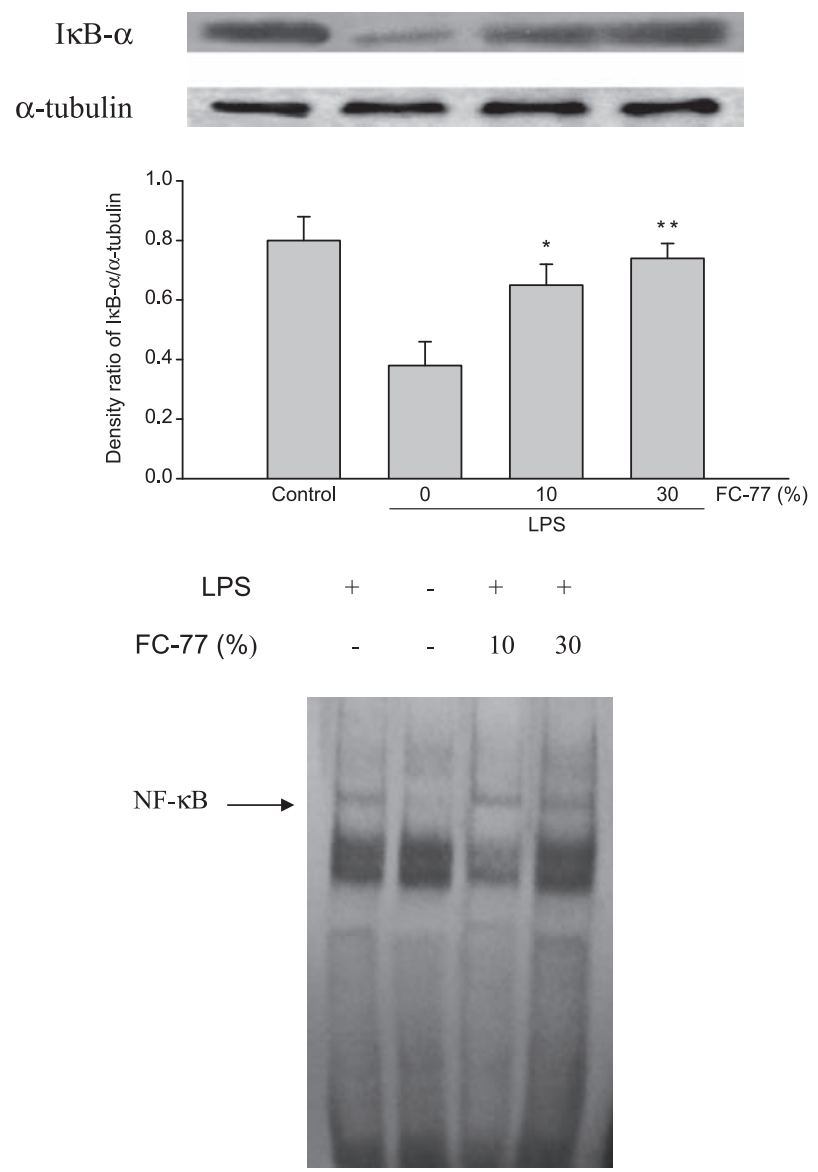

Fig. 4. Effect of FC-77 on cytosolic $\mathrm{I} \kappa \mathrm{B}-\alpha$ degradation and nuclear NF- $\kappa$ B activation in LPS-treated RAW 264.7 macrophages. A) After incubation with LPS for $1 \mathrm{~h}$ in the presence or absence of FC-77, the $\mathrm{I} \kappa \mathrm{B}-\alpha$ expression in the cytosolic protein of cells was measured. Values of each group are expressed as the mean \pm S.E.M. of five similar experiments. $* P<0.05, * * P<0.01$, compared with that in LPS (alone)-stimulated cells. B) After incubation with LPS for $1 \mathrm{~h}$, the nuclear extracts of cells were prepared for the assay of NF- $\kappa \mathrm{B}$ activation with a NF- $\kappa$ B EMSA kit. The result shown is representative of four independent experiments.

finding observed in this study was that FC-77 enhanced the production of IL-10 in LPS-stimulated RAW 264.7 macrophages. Accordingly, FC-77 may decrease the ratio of pro-inflammatory/anti-inflammatory cytokine, subsequently leading to an inhibition of NO production.

Many of the transcriptional effects of inflammatory genes and cytokines including iNOS and TNF- $\alpha$ are mediated by activation of NF- $\kappa \mathrm{B}(26,27)$. To further investigate the molecular mechanism involved, the effect of FC-77 on NF- $\kappa$ B activation was evaluated. In quiescent cells, NF- $\kappa \mathrm{B}$ is present in the cytoplasm and is bound with the inhibitory molecule $\mathrm{I} \kappa \mathrm{B}-\alpha$. Upon activation by LPS, I $\kappa \mathrm{B}-\alpha$ is rapidly phosphorylated, causing a dissociation of the $\mathrm{I} \kappa \mathrm{B}-\alpha / \mathrm{NF}-\kappa \mathrm{B}$ complex. Then, active NF- $\kappa \mathrm{B}$ translocates into the nucleus and

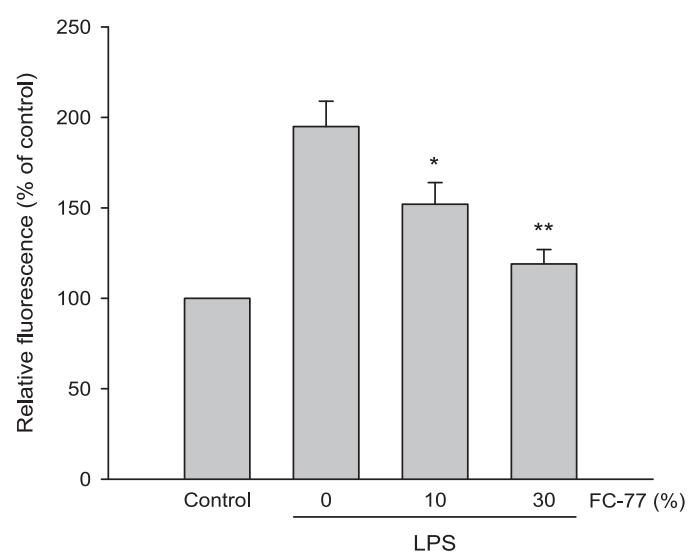

Fig. 5. Effect of FC-77 on intracellular ROS formation in LPStreated RAW 264.7 macrophages. Cells were preincubated with FC-77 for $1 \mathrm{~h}$ and LPS was added for an additional $3 \mathrm{~h}$ to measure ROS production. Intracellular ROS levels were determined by labeling with DCFH-DA, and the fluorescent intensity was analyzed by a flow cytometry system. The cells cultured with DMEM alone acted as the control group. The relative intracellular ROS formation was expressed as $\%$ fluorescence intensity of the control. ${ }^{*} P<0.05$, $* * P<0.01$, compared with that in LPS (alone)-treated cells $(\mathrm{n}=5$, each group).

triggers an induction of iNOS and pro-inflammatory cytokines $(26,28)$. In the present study, we also found that treatment with FC-77 prevented LPS-induced $\mathrm{I} \kappa \mathrm{B}-\alpha$ degradation in the cytoplasm and NF- $\kappa \mathrm{B}$ activation in nuclei, which is similar to our previous study (11). The result further indicates that inhibition of NF- $\kappa \mathrm{B}$ activation by FC-77 may be an important mechanism accounting for the suppression of iNOS expression. In addition, a direct inhibition of NOS activity by FC-77 may be another mechanism causing the attenuation of NO formation. Although FC-77 markedly inhibited LPS-induced iNOS expression and activity, nitrite production was not completely suppressed by FC-77, especially at the high dose. The finding may suggest that other NO-producing enzymatic systems including xanthine oxidoreductase and mitochondrial enzymes (29) may be also involved in the formation of NO. However, the true mechanisms of action require further study.

In the inflammatory response, overproduction of ROS has been proposed as an important cause of cell and tissue damage (30). Furthermore, NO can produce highly reactive species, most notably peroxynitrite, by interaction with superoxide anion. Then, peroxynitrite is decomposed to form hydroxyl radical, which may cause further damage to cells and tissues (31). Importantly, $\mathrm{ROS}$ is also a major inducer of NF- $\kappa \mathrm{B}$ activation, subsequently leading to the induction of several proinflammatory mediators (32). The concept is supported by the finding that treatment with antioxidant suppressed 
$\mathrm{NO}$ production through inhibition of NF- $\kappa \mathrm{B}$ activation in endotoxin or cytokine-treated macrophages $(33,34)$. Therefore, the antioxidant effect of FC-77 observed in this study may be a potential additional mechanism accounting for the attenuation of the iNOS/NO pathway. However, other possible mechanisms, including reduction in phagocyte function due to modification of cell membrane receptor-ligand binding (35) and altered membrane fluidity (36) by PFCs, may be also involved in the anti-inflammatory activity of FC-77. In summary, the present study demonstrated that FC-77 significantly inhibited LPS-induced iNOS expression and NO production, which may be due to the attenuation of proinflammatory/anti-inflammatory cytokine ratio, NF- $\kappa \mathrm{B}$ activation, and ROS formation.

\section{Acknowledgements}

This study was partially supported by a research grant from the National Science Council of Taiwan, Republic of China (NSC 932314-B-016050). We also thank assistant Ting-Hui Chu for her skillful technical assistance.

\section{References}

1 Hirschl RB, Tooley R, Parent AC, Johnson K, Barlett RH. Improvement of gas exchange, pulmonary function, and lung injury with partial liquid ventilation. Chest. 1995;108:500-508.

2 Hirschl RB, Tooley R, Parent AC, Johnson K, Barlett RH. Evaluation of gas exchange, pulmonary compliance, and lung injury during total and partial liquid ventilation in the acute respiratory distress syndrome. Crit Care Med. 1996;21:1270 1278.

3 Haeberle HA, Nesti F, Dieterich H-J, Gatalica Z, Garofalo RP. Perflubron reduces lung inflammation in respiratory syncytial virus infection by inhibiting chemokine expression and nuclear factor $-\kappa \mathrm{B}$ activation. Am J Respir Crit Care Med. 2002;165: 1433-1438.

4 Jeng M-J, Kou YR, Sheu C-C, Hwang B. Effects of partial liquid ventilation with $\mathrm{FC}-77$ on acute lung injury in newborn piglets. Pediatr Pulmonol. 2002;33:12-21.

5 Shaffer TH, Wolfson MR, Clark LC. Liquid ventilation. Pediatr Pulmonol. 1992;14:102-109.

6 Raghavendran K, Pryhuber GS, Chess PR, Davidson BA, Knight PR, Notter RH. Pharmacotherapy of acute lung injury and acute respiratory distress syndrome. Curr Med Chem. 2008;15:19111924.

7 Thomassen MJ, Buhrow LT, Wiedemann HP. Perflubron decreases inflammatory cytokine production by human alveolar macrophages. Crit Care Med. 1997;25:2045-2047.

8 Croce MA, Fabian TC, Patton JH Jr, Melton SM, Moore M, Trenthem LL. Partial liquid ventilation decreases the inflammatory response in the alveolar environment of trauma patients. J Trauma. 1998;45:273-280.

9 Smith TM, Steinhorn DM, Thusu K, Fuhrman BP, Dandona P. A liquid perfluorochemical decreases the in vitro production of reactive oxygen species by alveolar macrophages. Crit Care
Med. 1995;23:1533-1539.

10 Rotta AT, Gunnarsson B, Hernan LJ, Fuhrman BP, Steinhorn DM. Partial liquid ventilation with perflubron attenuates in vivo oxidative damage to proteins and lipids. Crit Care Med. 2000;28:202-208.

11 Chang H, Kuo FC, Lai YS, Chou TC. Inhibition of inflammatory responses by FC-77, a perfluorochemical, in lipopolysaccharidetreated RAW 264.7 macrophages. Intensive Care Med. 2005;31:977-984.

12 Moncada S, Palmer RMJ, Higgs EA. Nitric oxide: physiology, pathophysiology, and pharmacology. Pharmacol Rev. 1991;43: 109-142.

13 Vane JR, Mitchell JA, Appleton I, Tomlinson A, Bishop-Bailey $\mathrm{D}$, Croxtall $\mathrm{J}$, et al. Inducible isoforms of cyclooxygenase and nitric oxide synthase in inflammation. Proc Natl Acad Sci U S A. 1994;91:2046-2050.

14 Blantz RC, Munger K. Role of nitric oxide in inflammatory conditions. Nephron. 2002;90:373-378.

15 Chou TC, Li CY, Wu TM, Tang ST, Lee AR, Ding YA. Beneficial effect of HCL-31D in murine models of endotoxaemia. Naunyn Schmiedebergs Arch Pharmacol. 2001;364 213-219.

16 MacMicking JD, Nathan C, Hom G, Chartrain N, Fletcher DS, Trumbauer M, et al. Altered responses to bacterial infection and endotoxic shock in mice lacking inducible nitric oxide synthase. Cell. 1995;81:641-650.

17 Fujii Y, Goldberg P, Hussain SNA. Contribution of macrophages to pulmonary nitric oxide production in septic shock. Am J Respir Crit Care Med. 1998;157:1645-1651.

18 West MA, Li MH, Seatter SC, Bubrick MP. Pre-exposure to hypoxia or septic stimuli differentially regulates endotoxin release of tumor necrosis factor, interleukin-6, interleukin-1, prostaglandin $E_{2}$, nitric oxide, and superoxide by macrophages. J Trauma. 1994;37:82-89.

19 Tsao L-T, Tsai P-S, Lin R-H, Huang L-J, Kuo S-C, Wang J-P. Inhibition of lipopolysaccharide-induced expression of inducible nitric oxide synthase by phenolic (3E)-4-(2-hydroxyphenyl) but-3-en-2-one in RAW 264.7 macrophages. Biochem Pharmacol. 2005;70:618-626.

20 Ahn KS, Noh EJ, Zhao HL, Jung SH, Kang SS, Kim YS. Inhibition of inducible nitric oxide synthase and cyclooxygenase II by Platycodon grandiflorum saponins via suppression of nuclear factor $-\kappa \mathrm{B}$ activation in RAW 264.7 cells. Life Sci. 2005; 76: 2315-2328.

21 Nathan C, Xie QW. Regulation of biosynthesis of nitric oxide. J Biol Chem. 1994; 269:13725-13728.

22 Wang P, Wu P, Siegel MI, Egan RW, Billah MM. IL-10 inhibits transcription of cytokine genes in human peripheral blood mononuclear cells. J Immunol. 1994;153:811-816.

23 Dokka S, Shi X, Leonard S, Wang L, Castranova V, Rojanasakul Y. Interleukin-10-mediated inhibition of free radical generation in macrophages. Am J Physiol. 2001;280:L1196-L1202.

24 Huang CJ, Stevens BR, Nielsen RB, Slovin PN, Fang X, Nelson $\mathrm{DR}$, et al. Interleukin-10 inhibition of nitric oxide biosynthesis involves suppression of CAT-2 transcription. Nitric Oxide. 2002;6:79-84.

25 Dugas N, Palacios-Calender M, Dugas B, Riveros-Moreno V, Delfraissy JF, Kolb JP, et al. Regulation by endogenous interleukin-10 of the expression of nitric oxide synthase induced after ligation of $\mathrm{CD} 23$ in human macrophages. Cytokine. 
1998;10:680-689.

26 Tak PP, Firestein GS. NF-kappaB. a key role in inflammatory diseases. J Clin Invest. 2001;170:7-11.

27 Sun Z, Andersson R. NF-kappa B activation and inhibition: a review. Shock. 2002;18:99-106.

28 Xie Q-W, Kashiwabara Y, Nathan C. Role of transcriptional factor NF- $\kappa \mathrm{B} / \mathrm{Rel}$ in induction of nitric oxide synthase. J Biol Chem. 1994;269:4705-4708.

29 Lundberg JO, Weitzberg E. NO generation from nitrite and its role in vascular control. Arterioscler Thromb Vasc Biol. 2005; 25:915-922.

30 Victor VM, Rocha M, Esplugues JV, De la Fuente M. Role of free radicals in sepsis: antioxidant therapy. Curr Pharm Des. 2005;11:3141-3158.

31 Kukreja RC, Hess ML. The oxygen free radical system: from equations through membraneprotein interactions to cardiovascular injury and protection. Cardiovasc Res. 1992;26:641655.

32 Gloire G, Legrand-Poels S, Piette J. NF-kappaB activation by reactive oxygen species: fifteen years later. Biochem Pharmacol. 2006;30:1493-1505.

33 Pahan K, Sheikh FG, Namboodiri AM, Singh I. N-Acetyl cysteine inhibits induction of NO production by endotoxin or cytokine stimulated rat peritoneal macrophages, $\mathrm{C}_{6}$ glial cells and astrocytes. Free Radic Biol Med. 1998;24:39-48.

34 Han Y-J, Kwon Y-G, Chung H-T, Lee S-K, Simmons RL, Billiar TR, et al. Antioxidant enzymes suppress nitric oxide production through the inhibition of NF- $\kappa \mathrm{B}$ activation: role of $\mathrm{H}_{2} \mathrm{O}_{2}$ and nitric oxide in inducible nitric oxide synthase expression in macrophages. Nitric Oxide. 2001;5:504-513.

35 Smith TM, Steinhorn DM, Thusu K, Fuhrman BP, Dandona P. A liquid perfluorochemical decreases the in vitro production of reactive oxygen species by alveolar macrophages. Crit Care Med. 1995;23:1533-1539.

36 Gause EM, Rowlands JR. Effects of fluorocarbon inhalants upon alveolar macrophages. Proc West Pharmacol Soc. 1976;19:373380 . 